\title{
JOURNAL
}

of Health Inequalities

\section{Memories of John William Powles (1943-2018)}

\author{
Witold A. Zatoński ${ }^{1,2}$ \\ 'Health Promotion Foundation, Nadarzyn, Poland \\ 2European Observatory of Health Inequalities at the President Stanisław Wojciechowski State University of Applied \\ Sciences in Kalisz, Poland
}

During the Calisia World Conference on Family Health on 9-10 June 2019 in Kalisz, Poland [1], I dedicated my welcome lecture entitled "One hundred years of health in Poland" to the memory John Powles.

John Powles, MB BS MA FFPH, was a Senior Lecturer in Public Health Medicine, Department of Public Health and Primary Care, Institute of Public Health, Cambridge, UK. John was also my mentor, colleague, and friend. Thanks to John and Tony McMichael, I was able to publish my first important English-language scientific paper. Later, John and I spent a few years working together on a report on the health Iron Curtain still dividing Europe, which remains one of the most significant and cherished pieces of research I have been involved in: the HEM - Closing the Gap - Project [2].

John was a Principal Co-Investigator of the HEM project. HEM - Closing the Gap - Reducing Premature Mortality. Baseline for Monitoring Health Evolution Following Enlargement was a three-year project no. 2003121 submitted within a framework of the Public Health Program 2003-2008, DG Sanco [2]. John was also a member of the project's Expert Group. His great expertise in the nutritional factors underpinning cardiovascular diseases, his active participation in preparing the individual reports, scientific papers, and especially the HEM Blueprint Chapter "Policy implications and recommendations", were invaluable for the success of this important project. The HEM report went on to become one of the fundamental studies describing the health differences between Eastern and Western Europe and outlining the public health strategy to close this gap.

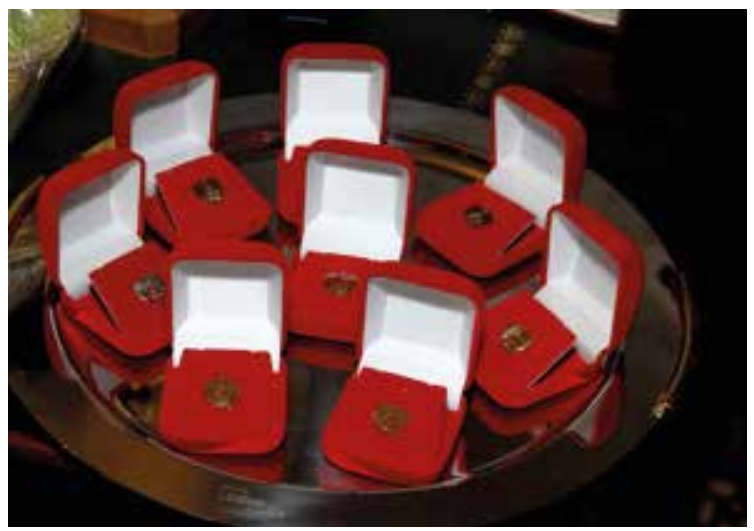

PHOTO 1. Golden Honorary Awards of the Health Promotion Foundation

\footnotetext{
Joint publications:

Zatoński W, McMichael AJ, Powles JW. Ecological study of reasons for sharp decline in mortality from ischaemic heart disease in Poland since 1991. BMJ 1998; 316: 1047-1051.

McMichael A, Zatoński W. Environmental, behavioral, and socioeconomic influences: tackling the historical jigsaw puzzle of health in Central and Eastern Europe. Int J Occup Environ Health 1996; 2: 161-163.

Didkowska J, Mańczuk M, McNeill A, Powles J, Zatoński W. Lung cancer mortality at ages 35-54 in the European Union: ecological study of evolving tobacco epidemics. BMJ 2005; 331: 189-191.

Powles JW, Zatoński W, Vander Hoorn S, Ezzati M. The contribution of leading diseases and risk factors to excess losses of healthy life in Eastern Europe: burden of disease study. BMC Public Health 2005; 5: 116.

Rehm J, Sulkowska U, Mańczuk M, Boffetta P, Powles J, Popova S, Zatoński W. Alcohol accounts for a high proportion of premature mortality in central and eastern Europe. Int J Epidemiol 2007; 36: 458-467.

Zatoński WA, Manczuk M, Powles J, Negri E. Convergence of male and female lung cancer mortality at younger ages in the European Union and Russia. Eur J Pub Health 2007; 17: 450-454.

Powles J, Shroufi A, Mathers C, Zatoński W, La Vecchia C, Ezzati M. National cardiovascular prevention should be based on absolute disease risks, not levels of risk factors. Eur J Public Health 2009; 20: 103-106.
} 
John was a mentor to many Central and Eastern European scientists and scholars, especially in Bulgaria and Poland, and his influence on developing European epidemiology cannot be overemphasised. In 2019, the Health Promotion Foundation awarded John with its Golden Honorary Award for his substantial contribution to public health research in Poland and Eastern Europe (Photo 1).

I asked John's family and colleagues to prepare his curriculum vitae that would accompany this tribute to his life and work (see article: John William Powles obituary (1943-2018) on pages 115-116) [3].

\section{DISCLOSURE}

The author reports no conflict of interest.

\section{References}

1. Janik-Koncewicz K. Report from the Calisia World Conference on Family Health, Kalisz, Poland, 9-10 June 2019. J Health Inequal 2019; 5: 2-10.

2. Zatoński $W$ and the HEM Project team. Closing the health gap in European Union. Cancer Centre and Institute, Warsaw 2008. 3. Brayne C, Gouda HN. John William Powles obituary (19432018). J Health Inequal 2019; 5: 115-116. 